\title{
CLOSE CORPORATION LEGISLATION: A SURVEY AND AN EVALUATION $\dagger$
}

\author{
F. HODGE O'NEAL*
}

Elvin R. Latty, before turning his energies to law school administration, was the most innovative and resourceful of the pioneer draftsmen of close corporation legislation. This article is dedicated to him in recognition of the tremendous impact his thinking has had on the development of such legislation.

This article first notes the general failure of legislatures, at least before 1960, to differentiate in corporation statutes between close corporations and public-issue corporations. It then discusses the growing recognition of the distinctive needs and problems of close corporations and the legislative efforts (many drawing on Dean Latty's ideas) that have been made to meet these needs and cope with these problems. Finally, it points out inadequacies in existing close corporation legislation and makes suggestions for future lines of development in legislation dealing with close corporations.

\section{Historical Failure of Legislatures to Differentiate Between Close Corporations and Public-Issue Corporations}

Many corporate concepts and principles, undoubtedly created with public-issue corporations primarily in mind, are ill-adapted to close corporations. Although the nature and methods of operation of the two kinds of corporations are utterly different, in the past and especially before 1960 the corporation statutes generally set forth the same rules for the governance of both public-issue and close corporations.' As one experienced attorney noted, a court normally had to

\footnotetext{
$\dagger$ This article is based on $\$ 1.13-.14 \mathrm{c}$ of $1 \mathrm{~F} . \mathrm{H}$. O'Neal, Close Corporations: LaW and Practice (2d ed. 1971).

* James B. Duke Professor of Law, Duke University. A.B. 1938, J.D. 1940, Louisiana State University; J.S.D. 1949, Yale University; S.J.D. 1954, Harvard University.

1. The lack of a differentiation is graphically pointed out in Weiner, Legislative Recognition of the Close Corporation, 27 Mich. L. Rev. 273 (1929). See also In re Klaus, 67 Wis. $401,406-07,29$ N.W. 582, 584 (1886). As early as the 1880's Professor Williston observed that "[t]he most striking peculiarity found on first examination of the history of the law of business corporations is the fact that different kinds of corporations are treated without distinction, and, with few exceptions, as if the same rules were applicable to all alike." Williston, History of the Law of Business Corporations Before 1800, 2 HARv. L. REv. 105 (1888).
} 
answer each question concerning a close corporation "by struggling to fit it into the pattern of statutory and case law developed for corporations of largely different character."2 In some states, little or nothing has been done even in recent years to modify statutes unfavorable to close corporations. ${ }^{3}$

Prior to World War II, scholars working and writing in the field of corporate law and most lawyers with a business practice seem to have been oblivious to the special needs and problems of the close corporation. Books of corporate forms, for example, contained abundant specimen charters, by-laws, and other documents designed for public-issue corporations but provided virtually no specimen documents adapted to close corporations. Even among the more experienced corporate practitioners, only a rare lawyer really attempted to tailor the corporate form to the distinctive needs of a closely held enterprise.

\section{Pleas for Corrective Legislation: Delays and Opposition}

Great Britain and some of the countries of continental Europe have long had special statutes governing the private company. ${ }^{4}$ Since World War II, strong pleas have been made urging the enactment in this country of similar comprehensive statutes to govern close corporations, ${ }^{5}$ and these pleas have become more frequent since the early 1950's. ${ }^{6}$

2. Scott, The Close Corporation in Contemporary Business, 13 Bus. LAw. 741, 743 (1958).

3. Because of restrictive or ambiguous statutes in such statcs, even an expericnced and resourceful corporation lawyer may find it difficult or impossible to set up with any assurance of validity the kind of control pattern participants in a close corporation may want. See Note, Some Specific Needs of the Close Corporation Not Met Under the Minnesota Business Cor. proation Act: Suggestions for Statutory Relief, 54 MiNN. L. REv. 1008 (1970).

4. For a discussion of the British Act, see McFadyean, The American Close Corporation and lts British Equivalent, 14 Bus. LAw. 215 (1958). See also Haskell, The American Close Corporation and Its West German Counterpart: A Comparative Study, 21 ALA. L. REv. 287 (1969).

5. In particular, see Winer, Proposing a New York "Close Corporation Law." 28 Corngll L.Q. 313 (1943). One commentator has stated:

It would seem like an intelligent approach to the general problem of incorporation would require at least three types of general incorporation laws in each state: One for the single incorporator, another for the small concern, and a third for the extensive business setup, for the purposes of mass production. Rutledge, Significant Trends in Modern Incorporation Statutes, 22 WASH. U.L.Q. 305, 339 (1937).

6. See Bradley, A Comparative Evaluation of the Delaware and Maryland Close Corpora. tion Statutes, 1968 Duke L.J. 525; Bradley, Towards a More Perfect Close Corporation-The Need for More and Improved Legislation, 54 Geo. L.J. 1145 ( 1966); Ham, Suggestions for Moderninzing the Kentucky General Corporation Law to Meet the Needs of Close Corpora- 
The legislative response of the states has been slow. Until about 1960 , only a relatively few isolated provisions dealing with close corporation problems had been added to the corporate statutes. Undoubtedly, one reason for this delay was the absence of any organized group, adversely affected by the existing laws, which was capable of exerting pressure on the legislatures. ${ }^{7}$ Unlike big business management, which is well represented when changes are being made in corporation statutes, small business owners, especially holders of minority interests, usually do not play an important role in statutory revisions.

Since 1960, a legislative breakthrough has occurred, with many states adding to their corporate statutes provisions designed to meet the more pressing close corporation problems. Even now, however, only a handful of states have adopted a separate close corporation statute. Most law revision committees have rejected the idea of a completely separate legislative treatment of the close corporation either in a new and distinct statute or in a separate chapter of the business corporation statute. For example, the Corporation Law Revision Commission of New Jersey, after much study, stated that it had "determined, as have its counterparts in most states, that it was not desirable to have a separate law govern the close corporation, as distinct from all other corporations generally."

The reasons for the rejection of separate treatment appear to be threefold. First, legislatures have encountered difficulties in arriving

tions, 52 KY. L.J. 527 (1964); Luna, Protection of Minority Interests Through Stockholders' Agreements: A Commentary on Section 9 of the New York Stock Corporation Law, 28 PhiLippine L.J. 506, 535 (1953); Oppenheim, The Close Corporation in California-Necessity of Separate Treatment, 12 Hast. L,J. 227 (1961); Powers, Cross Fire on the Close Corporation: Norms Versus Needs, 11 U. FLA. L. Rev. 433, 473 (1958); Wolens, A Round Peg-A Square Hole: The Close Corporation and the Law, 22 Sw. L.J. 811 (1968); Note, The Need for Legislative Recognition of Utah's Close Corporation, 1970 UTAH L. REv. 270.

In the Afterword to Note, A Plea for Separate Statutory Treatment of the Close Corporation, 33 N.Y.U.L. Rev. 700 (1958), Professor Miguel A. De Capriles, focusing on the experience of New York, commented:

[A]s a matter of policy, there is no justification for a formalistic - perhaps one might even say, sadistic-insistence upon an unnecessary and unsuitable internal structure or operational organization as a condition of limited liability in the close corporation. . . . To resolve these problems by the enactment of a special close corporation statute would, in my judgment, be in the public interest. 33 N.Y.U.L. REv. 743, 745 (1958).

7. Hetherington, Special Characteristics, Problems and Needs of the Close Corporation. 1969 U. ILL. L.F. 1.

8. N.J. CORPORAtion Law Revision COMM'N REPORT, reprinted in N.J. STAT. ANN. 14A:1-1, at xii (1969). See generally Kessler, Hooray (?) for the Model Act-The 1969 Revision and the Close Corporation, 38 FoRD. L. REv. 743 (1970). 
at a satisfactory definition of the close corporation..$^{9}$ This problem is illustrated by the experience of the New York Joint Legislative Committee to Study Revision of the Corporation Laws, the committee that drafted the New York Business Corporation Law. At the very inception of the revision study, the Committee explored the desirability of a separate "Close Business Corporation Law," but after investigation concluded that the close corporation could not be defined with sufficient precision to delineate clearly between close corporations and public-issue corporations. ${ }^{10} \mathrm{~A}$ second reason for the failure of legislatures to enact separate close corporation legislation is a fear that separate lcgislation may bind close corporations to a small business structure, thereby impeding their growth and hindering the gradual evolution of the more successful of the closely held enterprises into public-issue corporations. A third, undocumented reason for legislative rejection of separate treatment is that members of the corporation bar serving as advisors or draftsmen for new corporation statutes may have opposed separate legislative treatment of small incorporated enterprises because such treatment might tend to isolate the giant companies politically (by depriving them of their identification with politically potent small business) and thus might lead to separate and more severe regulation and taxation for the huge corporations.

\section{Statutory Provisions with Some Utility for Close CORPORATIONS}

Even though most state legislatures have declined to enact separate statutes for close corporations, the efforts of the writers who have pleaded so eloquently for legislative recognition of the close

9. See N.Y. Joint Legislative Comm. To Study Revision of Corporation Laws, (First) Interim RePort, N.Y. Legis, Doc. No. 17, 180th Sess. 119-20 (1957), discussed in Hoffman, New Horizons for the Close Corporation in New York Under Its New Business Corporation Law, 28 Brooklyn L. Rev. 1, 2 (1961); Folk, The Model Act and the South Carolina Corporation Law, 15 S.C.L. Rev. 275, 282 (1963); Latty, The Close Corporation and the New North Carolina Business Act, 34 N.C.L. Rev. 432, $455-57$ (1956).

As early as 1948, the New York Law Revision Commission struggled unsuccessfully with the definitional problem. At one point the Commission stated that "no satisfactory way of defining the genuine close corporation for purposes of a statute has ever been found." N.Y. LAw Revision Comm'n Rep. 386 (1948). But see Del. Code ANn. tit. 8, § 342 (Supp. 1968); Fla. Stat. Ann. $\$ 608.70$ (Supp. 1972); Md. AnN. Code, art. 23, § 100 (Supp. 1971); PA. Stat. Ann. tit. 15, $\$ \$ 1372-74$ (Supp. 1972). See generally F.H. O'Neal, Close CorporaTIONS: LAW AND PRACTICE $§ 1.02$ (1971).

10. See N.Y. Joint Legislative Comm. to Study Revision of Corporation laws, supra note 9, at 115-20; Hoffman, supra note 9, at 2. 
corporation have not been in vain. Corporation statutes enacted or extensively revised since World War II typically contain a number of provisions useful to lawyers organizing or counseling close corporations." Some of these statutory provisions, equally applicable to close corporations and public-issue corporations, give an increased flexibility to the corporate form and thus permit a tailoring of the corporate device to the needs of closely held enterprises. Other provisions, although in many instances not limited expressly to close corporations, ${ }^{12}$ were drafted primarily to meet the needs of close corporations, and in practical operation apply largely, if not exclusively, to such corporations.

Many of the new statutory provisions make the corporate form more adaptable. Enactments in various states accomplish one or more of the following: (1) authorize the use of optional clauses in a corporation's charter ${ }^{13}$ or special provisions in its by-laws; ${ }^{14}(2)$ permit a corporation to be formed by a single incorporator; ${ }^{15}$ (3) permit a corporation to have less than the traditional minimum of three directors; ${ }^{16}(4)$ authorize high quorum and high vote requirements for

11. See Folk, Corporation Statutes: 1959-1966, 1966 DUKE L.J, 875, 947; O'Neal, Recent Legislation Affecting Close Corporations, 23 LaW \& Contemp. ProB. 341 (1958). One commentator has contended: "[T]he effect of most modern amendment programs dealing with basic provisions of the corporation acts has been to modify them in the interest of the close corporation. Our general corporation laws seem to be in the process of becoming general close corporation laws with only incidental relevance to large companies." Manne, Our Two Corporation Systems: Law and Economics, 53 Va. L. REv. 259, 284 (1967). See also ABA MODEL Bus. CoRP. ACT. ANN. $\$ 35$, Special Comment at 756 (2d ed. 1971).

12. The difficulty of defining the close corporation and drawing a sharp line between it and the public-issue corporation accounts, in part, for the failure to limit the application of some of the new statutes to close corporations. See notes 9-10 supra and accompanying text.

13. N.Y. Bus. CoRP. LAW $\S 402$ (b) (McKinney 1963).

14. E.g., id. § 601(c); OHı Rev. CODE ANN. § 1701.15 (Page 1964).

15. E.g., Ga. Code ANN. $\$ 22-801$ (1970); Ill. ANN. Stat. ch. 32, § 157.46 (Smith-Hurd Supp. 1972); Mich. Comp. Laws ANN. § 450.3 (1967); Wis. Stat. AnN. § 180.44 (1957). See also OHto Rev. CODE ANN. § 1701.04(A) (Page Supp. 1971) (statute ailows incorporation by a single person, not necessarily a natural person). One commentator has stated: "These enactments should go far in overcoming the notorious practices of employing dummy or accommodation incorporators and directors, and of recording and certifying minutes of meetings that are not held. These are moves in the direction of bringing the laws into conformity with practice." Spoerri, One Incorporator-One Director, 19 Bus. Law. 305, 308 (1963). For the view that such statutes do not go far enough to accomplish their purposes and that perpetuation of existing practices in regard to the one-man corporation may be simpler, see Folk, supra note 11, at 878; Garrett, John Doe Incorporates Himself, 19 Bus. LaW. 535 (1964); Spoerri, Business Corporations: Statutory Developments in 1964 and 1965, 21 Bus. LAw. 1079, 1080 (1966).

16. E.g., Del. Code AnN. tit. 8, § 141(b) (Supp. 1968); GA. Code ANN. § 22-702(a) (1970); Ill. ANN. Stat. ch. 32, \& 157.34 (Smith-Hurd Supp. 1972); Oh10 Rev. Code ANN. 
shareholder and director action; ${ }^{17}(5)$ relax the requirements of formal corporate meetings and permit directors and shareholders to act by unanimous written consent; ${ }^{18}(6)$ allow directors to meet by telephone conference. $^{19}$

Other statutory provisions that may be useful to close corporations effect the following: (1) authorize restrictions on the transfer of stock $;^{20}(2)$ empower directors to fix their own compensation as directors and officers; ${ }^{21}$ (3) sanction shareholder agreements which impinge upon powers traditionally within the province of the board of directors or which otherwise depart in important respects from the traditional pattern of corporate management; ${ }^{22}$ (4) permit charter provisions which restrict the discretion of directors or provide that the shareholders shall manage the corporation; ${ }^{23}(5)$ permit special contractual arrangements among the shareholders that provide when and under what circumstances the corporation will be dissolved or set up nonstatutory dissolution procedures; ${ }^{24}(6)$ authorize judicial dissolution of a corporation in the event of deadlock among the shareholders

$\S 1701.56(\mathrm{~A})$ (Page Supp. 1971). These statutes provide that where the corporation has less than three shareholders, the number of directors may be less than three but not less than the number of shareholders.

A 1966 amendment to the Kentucky corporation statute permits a corporation, irrespective of the number of its shareholders, to have a one-man board of directors. KY. REV. STAT. ANN. $\S 271.345(1969)$.

17. E.g., GA. CODE ANN. $\S 22-609$ (1970); MD. ANn. Code art. 23, § 103 (Supp. 1971); N.Y. Bus. CoRP. LAW $\$ 616,709$ (McKinney 1963); Wis. Stat. ANN. $\$ 180.28,180.35$ (1957).

18. E.g., Ga. CODE ANN. \$ 22-603 (1970); Mrch. CoMp. LAws ANN. § 450.13 (1967). See also N.Y. Bus. CoRP. LAw $\S 404$ (b) (McKinney 1963), providing that any action permitted to be taken at the organization meeting of the incorporator or incorporators may be taken without a meeting if each incorporator or his attorney-in-fact signs an instrument setting forth the action so taken.

19. Pa. Stat. Ann. tit. $15, \S 1008$ (E) (Supp. 1972).

20. E.g., CAL. CoRP. Code $\S 501$ (g) (West 1955); MD. ANN. Code art. 23, \& 101 (Supp. 1971); TEX. Bus. CoRP. ACt ANN. art. 2.22 (1956), as amended, (Supp. 1971). The Delaware statute expressly authorizes first options, buy-sell agreements, consent restraints, absolute prohibitions against transfers to designated persons or classes of persons, restraints which prescrve Subchapter S election, and "any other lawful restriction on transfer . . . " DEL. CODE ANN. tit. 8, § 202 (Supp. 1968).

21. E.g., Oho Rev. Code ANn. § 1701.60 (Page 1964); Wis. Stat. AnN. § 180.31 (1957),

22. E.g., Ga. Code ANN. § 22-61I (1970); N.Y. Bus. CorP. Law § 620 (McKinney 1953); N.C. GEN. STAT. § 55-68 (1965).

23. E.g., N.J. StaT. ANN. § I4A:5-21(2) (1969) (such a provision is permitted if provided for in the original certificate of incorporation or if authorized by amendment to the certificate by all shareholders).

24. E.g., N.C. Gen. Stat. § 55-125(3) (1965); Wyo. Stat. ANn. § 17-36.74 (1965). 
or directors (so-called "dissolution on deadlock" statutes); ${ }^{25}$ (7) authorize court appointment of a provisional director for a corporation with a board of directors that is evenly divided on management policies. $^{26}$

\section{Statutes Focusing on Close Corporations}

Perhaps the earliest statute avowedly passed to meet the special needs of close corporations was section 9 of the New York Stock Corporation Law, enacted in 1948. ${ }^{27}$ That statute authorized charter provisions fixing high quorums for shareholders' and directors' meetings and requiring high votes for shareholder and director action. Thereafter, organizers of New York close corporations, through the use of high quorum and high vote requirements, could protect minority shareholders by giving them power to veto corporate decisions. Section 9 was hailed at the time of its passage as the first important legislative recognition of the special management needs of close corporations. ${ }^{28}$

The first really extensive and imaginative statutory innovations on close corporations were included in the North Carolina Business Corporation Act, enacted in $1955 .{ }^{29}$ The commission which drafted that act made a diligent study of the peculiarities of close corporations, and many sections of the Act (although not limited in application to close corporations) were designed to meet the special needs of close corporations. Elvin R. Latty was a member of the commission and its principal draftsman. ${ }^{30}$

Two pioneering sections of the North Carolina Act deserve spe-

25. E.g., CAl. CoRP. CODE $\$$ 4650-51 (West 1955); Ill. ANN. STaT. ch. $32, \S \S 157.86$ (Smith-Hurd 1954), as amended, (Smith-Hurd Supp. 1972); N.J. STAT. ANN. § 14A-12-7 (1969).

26. E.g., CAL. CoRP. Code $\S 819$ (West 1955), as amended, (West Supp. 1972); Mo. ANN. STAT. $\$ 351.323$ (1966).

27. Ch. $862, \S 1,[1948]$ Laws of New York 1704. This statutory section has been superseded by N.Y. BuS. CoRP. LAw $\$$ 616, 709 (McKinney 1963).

28. See De Capriles \& Reichardt, 1947-1948 Survey of New York Law-Corporations, 23 N.Y.U.L.Q. REv. 747 (1948). Actually, high quorum and high vote requirements had been authorized in a number of states at an earlier date. E.g., CAL. CoRP. CODE $\$ 816$ (West 1955) (enacted in 1947); Del. Code ANN. tit. 8, § 102(b)(4) (1953) (enacted in 1935).

29. N.C. GEN. STATs. $\$ 55-1$ to-175 (1965). For other legislation taking a novel approach to problems of close corporations, see P.R. LAws ANN. tit. 14, $\$ 1102$ (c) (1962). For an early legislative proposal covering in detail the special problems of close corporations, see Winer, supra note 5, at 335-43 (1943).

30. See Latty, supra note 9; Latty, Powers \& Breckenridge, The Proposed North Carolina Business Corporation Act, 33 N.C.L. Rev. 26, 45, 51-52 (1954). 
cial attention. One of these sections ${ }^{31}$ contains the following provisions: (1) a contract between two or more shareholders to vote their shares as a unit for the election of directors shall be enforceable between the parties for as long as 10 years, if it is in writing and signed by the parties; (2) in a corporation whose shares are not generally traded in the markets, a written agreement to which all the shareholders have assented (whether embodied in the charter or bylaws or in a side agreement signed by all the parties) and which relates to any phase of the corporation's affairs shall not be invalidated on the ground that its effect is to make the parties partners among themselves; and (3) an agreement among some or all of the shareholders in a corporation, whether made solely among themselves or between one or more of them and a nonshareholder, is not invalid as between the parties on the ground that it interferes with the discretion of the board of directors; but by making such an agreement, the shareholders who are parties assume the same liability as directors for managerial acts. ${ }^{32}$

The other $\operatorname{section}^{33}$ authorizes judicial liquidation of a corporation in an action by a shareholder if the corporation's charter or any other written agreement among all the shareholders entitles the complaining shareholder to liquidation or dissolution at will, or on the occurrence of events which have taken place. ${ }^{34}$

The South Carolina Business Corporation Act ${ }^{35}$ passed in 1962, also focuses on the close corporation. The reporter of the draft version of that act stated that one of the principal guidelines of the draftsmen was the desire to permit shareholders in a close corporation to act in the corporation's internal affairs almost as freely as if they were involved in a partnership. ${ }^{36}$

31. N.C. Gen. Stat. § 55-73 (1965).

32. See also id. § 55-24(a), which reads as follows: "Subject to the provisions of the charter, the bylaws or agreements between the shareholders otherwise lawfill, the business and aftairs of a corporation shall be managed by a board of directors" (emphasis addcd).

33. Id. $\$ 55-125(\mathrm{a})$.

34. For a discussion of several other sections of the North Carolina act which are particularly applicable to close corporations, see Latty, supra note 9. For a discussion of amendments to the North Carolina act designed to strengthen shareholders' agreements, see Comiments on North Carolina 1959 Session Laws, 38 N.C.L. Rev. 154, 159-61 (1960).

35. S.C. Code ANN. 12-11.1 to -31.2 (Supp. 1971). For a discussion of provisions in this statute applicable to close corporations, see Myers, The Close Corporation Under the New South Carolina Law, 16 S.C.L. Rev. 577 (1964).

36. Folk, supra note 9, at 281. Draftsmen of future corporation laws would do well to consult the comprehensive and clearly written Reporter's Notes to the draft version of the 
One section of the South Carolina statute, ${ }^{37}$ designed to deal with dissension and deadlock in close corporations, gives the courts power to liquidate a corporation in an action brought by a shareholder whenever: (1) the directors are so divided respecting management that the votes required for action by the board of directors cannot be obtained, and the shareholders are unable to terminate the division, with the consequence that the corporation is suffering or will suffer irreparable injury, or the business and affairs of the corporation can no longer be conducted to the advantage of the shareholders generally; (2) the shareholders are so divided that they have failed, for a period which includes at least two consecutive annual meeting dates, to elect successors to directors whose terms have expired or would have expired upon the qualification of their successors; (3) the shareholders are so divided respecting management that the corporation is suffering or will suffer irreparable injury or the affairs of the corporation can no longer be conducted to the advantage of all the shareholders; (4) the acts of the directors or those in control of the corporation are illegal, fraudulent, dishonest, oppressive, or unfairly prejudicial either to the corporation or to any shareholder; (5) corporate assets are being misapplied or wasted; or (6) the petitioning shareholder has a right under the articles of incorporation to dissolution of the corporation at will or upon the occurrence of a specified event or contingency.

Another section of the statute ${ }^{38}$ allows the courts unusually broad remedial powers. It provides that, in an action filed by a shareholder to dissolve the corporation on the dissension and deadlock grounds discussed above, the court may make such order or grant such relief as it deems appropriate. This relief may include an order (1) cancelling or altering any provision contained in the corporation's articles or by-laws; (2) cancelling, altering, or enjoining any resolution or other act of the corporation; (3) directing or prohibiting any act of the corporation or of shareholders, directors, officers, or other persons party to the action; or (4) providing for the purchase at their fair

South Carolina Act. For additional material indicating that the draftsmen of the South Carolian statute were giving special attention to the problems of the small, closely held business, see S.C. Judicial Council, S.C. Bus. Corp. ACT ix-x (1961 Draft).

37. S.C. CODE ANN. \$ 12-22.15(a) (Supp. 1971).

38. Id. § 12-22.23. This provision was taken from Companies Act, $11 \& 12 \mathrm{Geo} .6$, c. 38, $\S 210$ (1948). As the reporter for the South Carolina act points out, section 210 of the English act "has not been invoked, in any reported case or known litigation, with respect to a publicly owned corporation, and indeed it is appropriate only to the closely held enterprise." S.C. Judicial COUNCIL, supra note 36, at 266. 
value of shares of any shareholder, either by the corporation or the other shareholders. The section goes on to state that such relief may be granted as an alternative to a decree of dissolution or may be afforded whenever the circumstances of the case are such that relief, rather than dissolution, would be appropriate. This provision gives a court broad power to adjust its decree to the particular problem before it, and thus to provide an adequate and lasting solution. In the absence of a statute, most courts in this country have not felt that they possessed such broad powers.

The New York Business Corporation Law, ${ }^{39}$ enacted in 1961 and effective in 1963, although oriented primarily toward public-issue corporations, has an extensive array of close corporation provisions. One of the most important provisions of the statute permits written shareholder agreements requiring that the shares held by the parties to the agreement be voted in a prescribed manner and validates, subject to certain conditions, terms in the certificate of incorporation restricting the management powers of the board of directors in favor of shareholder control..$^{40} \mathrm{~A}$ provision for shareholder control of the

39. N.Y. Bus. CoRp. Law (McKinney 1963). See Ch. 855 [1961] Laws of New York. Only a few of the Act's more significant provisions will be discussed in detail here. For further discussion of the provisions in the New York Business Corporation Law designed for the close corporation, see Hoffman, supra note 9; Stevens, Close Corporations and the New York Business Corporation Law of 1961, 11 Buffalo L. Rev. 481 (1962); 75 HARv. L. Rev. 852 (1962). See also Hetherington, Trends in Legislation for Close Corporations: A Comparison of the Wisconsin Business Corporation Law of 1951 and the New York Busines Corporation Law of 1961, 1963 Wis. L. Rev. 92; Latty, Some General Observations on the New Business Corporation Law of New York, 11 Buffalo L. Rev. 591, 600-03 (1962).

40. See N.Y. Bus. CoRP. LAw $\S 620(a)$-(c) (McKinney 1963), which provides:

(a) An agreement between two or more shareholders, if in writing and signed by the parties thereto, may provide that in exercising any voting rights, the sharcs held by them shall be voted as therein provided, or as they may agrec, or as determined in accordance with a procedure agreed upon by them.

(b) A provision in the certificate of incorporation otherwise prohibited by law because it improperly restricts the board in its management of the business of the corporation, or improperly transfers to one or more shareholders or to one or more persons or corporations to be selected by him or them, all or any part of such management othewise within the authority of the board under this chapter, shall nevertheless be valid:

(1) If all the incorporators or holders of record of all outstanding shares, whether or not having voting power, have authorized such provision in the certificate of incorporation or an amendment thereof; and

(2) If, subsequent to the adoption of such provision, shares are transferred or issued only to persons who had knowiedge or notice thereof or consented in writing to such provision.

(c) A provision authorized by paragraph (b) shall be valid only so long as no shares 
management of the corporation relieves the directors from the liability for managerial acts or omissions which is ordinarily imposed on directors and imposes that liability upon the shareholders authorizing the provision or consenting to it to the extent that and so long as the discretion or powers of the board are controlled by the provision. ${ }^{41}$

The New York Business Corporation Law also contains a provision that makes shareholders in a close corporation-but not shareholders in a public-issue corporation-liable for certain obligations owed by the corporation to its employees. ${ }^{42}$ Before the passage of the Business Corporation Law, New York imposed upon shareholders unlimited liability for debts, wages, and salaries (including "fringe benefits") which the corporation owed employees. ${ }^{43}$ In other words, the state made an important exception to the prineiple that shareholders are shielded from unlimited liability and risk only the funds they invest in the enterprise. While the Business Corporation Law retains shareholder liability for employee claims, it imposes this liability only on the ten largest shareholders in a corporation with no shares listed on a national securities exchange or quoted in an overthe-counter market by one or more members of a national securities association or its affiliate.

One piece of federal legislation which singled out the close corporation for special treatment warrants brief mention. Subchapter $\mathrm{S}^{44}$ of the Internal Revenue Code permits small business corporations that meet specified requirements to elect a special tax status in many respects similar to that of a partnership. Among the requirements for

of the corporation are listed on a national securities exchange or regularly quoted in an over-the-counter market by one or more members of a national or affiliated securities association.

Another section requires the existence of a provision authorized by paragraph (b) to be noted conspicuously on the face or back of every share certificate issued. $I d . \S 602(\mathrm{~g})$.

41. Id. $\S 620(f)$.

42. Id. $\$ 630$.

43. See Rogers \& McManus, Stockholders' Booby-Trap: Partnership Liabilities Under Section 7l. New York Stock Corporation Law, 28 N.Y.U.L. REv. 1149 (1953).

44. INT. REV. CODE of 1954, \$ 1371-77. Subchapter $S$ was added to the Internal Revenue Code by the Technical Amendments Act of 1958 and was originally enacted as Act of Sept. 2, 1958, Pub. L. No. 85-866, § 64, 72 Stat. 1650. See generally Anthoine, Federal Tax Legislation of 1958: The Corporate Election and Collapsible Amendment, 58 Colum. L. REv. 1146 (1958); Bittker \& Eustice, Corporate Elections Under Subchapter S, 39 CoLo. L. REv. 1 (1966); Patty, Qualification and Disqualification Under Subchapter S, N.Y.U. 18TH INST. ON FED. TAX. 661 (1960); Sherfy, Subchapter S of the Internal Revenue Code, 2 CoRP. Prac. Commentator 1 (No. 3, 1960); Swietlik, Subchapter S: What Is It and How Does It Work?, 44 MARQ. L. REv. 470 (1961). 
eligibility to elect this status are that the corporation be a domestic corporation, that it have only one class of stock, and that it have ten shareholders or less. Obviously, a public-issue corporation cannot qualify; many, if not most, close corporations can.

\section{The Integrated Close Corporation Statutes}

\section{The First Integrated Close Corporation Statute}

In 1963 Florida became the first state to enact a separate, integrated close corporation statute. ${ }^{45}$ The Florida statute is permissive, ${ }^{40}$ allowing a close corporation, which is defined as "a corporation for profit whose shares of stock are not generally traded in the markets maintained by securities dealers or brokers," ${ }^{47}$ to elect either to be governed by its provisions or to remain subject to the law applicable generally to corporations. The statute specifically states that acquisition of all of a corporation's shares by less than three shareholders will not render the corporation dormant or impair its cxistence. ${ }^{48}$

The Florida statute sanctions informal actions by directors and shareholders without the holding of formal meetings if written consent to such actions is gained from all persons who would be entitled to vote upon them..$^{49}$ Furthermore, a charter clause providing for the management of a close corporation's business by the shareholders rather than by a board of directors is permissible under this statute..$^{50}$ The statute also provides that shareholders of a close corporation may enter into an agreement-embodied in the articles of incorporation, in the by-laws, or in a written side agreement signed by all of the parties-which relates to any phase of the corporation's affairs..$^{51}$ The Florida law further states that a written agreement of this kind shall not be invalid as between the parties on the ground that it is an attempt by the parties to treat the corporation as if it were a partnership or to arrange their relationships in a manner that would be characteristic of a partnership, ${ }^{52}$ or, if the corporation is managed by a board of directors, on the ground that it so relates to the conduct

\footnotetext{
45. Fla. Stat. ANN. $\$ 608.70-.77$ (Supp. 1972).

46. Id. $\S 608.70(1)$.

47. Id. $\S 608.70(2)$.

48. Id. $\S 608.71(1)$.

49. Id. $\S 608.73-.74$.

50. Id. $\S 608.72$.

51. Id. $\S 608.75(1)$.

52. Id. $\S 608.75(2)$.
} 
of the corporation's affairs as to interfere with the discretion of the board of directors. ${ }^{53}$ However, such an agreement has the effect of relieving the directors of liability for managerial acts and imposing that liability upon those shareholders who are parties to the agreement. ${ }^{54}$ The statute contains a provision giving the shareholders of a close corporation who are entitled to elect a director of the corporation the authority "at any time [to] remove such director, with or without cause, by like action of the stockholders as required for the election of such director absent a contrary provision by agreement or in the by-laws or articles of incorporation." ${ }^{55}$ Finally, the law contains a typical provision for dissolution-on-deadlock, authorizing a court to dissolve a close corporation when the directors or shareholders are deadlocked, and arbitration or any other remedy provided for in writing by the shareholders has failed to break the impasse. ${ }^{56}$

The Florida statute is brief; its eight sections contain little that does not appear in other corporation statutes. In large part, the Florida statute merely assimilates provisions which appear in a somewhat different form scattered throughout the North Carolina Business Corporation Act. ${ }^{57}$ The Florida provisions, however, are not so well drafted as those incorporated in the North Carolina Act. In fact, the Florida statute contains a great deal of ambiguous language and leaves unanswered many questions of importance to close corporations. ${ }^{58}$ In view of these limitations and defects, the Florida close corporation statute is not likely to have a significant influence on the development of close corporation legislation.

53. Id. $\S 608.75(3)$.

54. Id.

55. Id. $\S 608.76$.

56. Id. $\S 608.77$.

57. N.C. GEN. STAT. $\$ 55-1$ to -175 (1965). For a discussion of the North Carolina-act, see notes 29-34 supra and accompanying text.

58. For a discussion of the uncertainties under the Florida statute "as to what corporations are governed by its provisions and what powers such corporations may possess," see Dickson, The Florida Close Corporation Act: An Experiment That Failed, 21 U. MiAm L. Rev. 842 (1967). For further discussion of the Florida statute, see Note, Statutory Recognition of the Close Corporation in Florida, 16 U. FLA. L. REv. 569 (1964). For a brief comparison of the Florida statute with provisions in the New York and North Carolina statutes, sec 77 HaRv. L. REv. 1551 (1964). For a comparison of the Florida statute with the close corporation provisions of Delaware and New York, see Comment, $A$ Comparison of the Close Corporation Statutes of Delaware, Florida and New York, 23 U. Miami L. Rev. 515 (1969). 


\section{More Recent Close Corporation Legislation}

In 1967 Delaware $^{59}$ and Maryland ${ }^{60}$ enacted close corporation statutes. The framers of the two statutes took entirely different approaches to the problems of close corporations; ${ }^{61}$ however, both statutes have innovative and forward-looking features, and undoubtedly will be carefully studied in the future by draftsmen of close corporation legislation. The Delaware plan has been adopted, with only minor modifications, by Pennsylvania in $1968^{62}$ and by Kansas in $1972 .^{63}$

The Delaware Plan. The Delaware close corporation statute is in the form of a separate subchapter of the state's General Corporation Law. ${ }^{64} \mathrm{~A}$ close corporation is defined in this subchapter as a corporation whose charter provides that (1) its outstanding stock shall be held by not more than a specified number of persons, not to exceed thirty; (2) all of its stock shall be subject to one or more restrictions on transfer; and (3) it shall make no "public offering" of its stock..$^{65} \mathrm{~A}$ corporation that meets these requirements can elect to become a "close corporation" and be subject to the provisions of the close corporation subchapter, or it can remain subject to the other provisions of the General Corporation Law. ${ }^{66}$

Under the terms of the Delaware statute a close corporation's

59. Del. Code ANN. tit. 8, $\S 341-56$ (Supp. 1968).

60. Md. ANn. Code art. 23, $\$ 100-11$ (Supp. 1971).

61. For an excellent article comparing the statutes, see Bradley, $A$ Comparative Evaluation, supra note 6 (concluding that the Maryland statute is "the best close corporation statute to date," $i d$. at 554). For a discussion of the Maryland close corporation statute, see Hall, The New Maryland Close Corporation Law, 27 MD. L. Rev. 341 (1967).

62. Pa. Stat. ANN. tit. 15, $\$ 1371-86$ (Supp. 1972).

63. 3 P-H CoRP. (Kan.) $\$ 125-40$ (1972).

64. Del. Code ANN. tit. 8, \$341-56 (Supp. 1968).

65. Id. § 342(a). As Professor Bradley points out, workable close corporation legislation is available to a corporation in Delaware, irrespective of the number of its shareholders or whether its stock is subject to transfer restrictions or has been offered for sale publicly, because under the Delaware General Corporation Law, a corporation, even though it does not qualify under the close corporation subchapter, will have or may be given the following characteristics: a board of directors consisting of only one member (\$ 141(b)); high director quorum and vote requirements ( $\$ 141(\mathrm{~b}))$; informal director action $(\S 141(\mathrm{f})$ ); broad delegation to committecs $(\S 141(\mathrm{c}))$; selection of corporate officers and agents by the shareholders $(\S 142(\mathrm{a}) \cdot(\mathrm{b}))$; stock transfer restrictions of the most stringent variety ( $(202)$; irrevocable proxies ( $(212)$; high shareholder quorum and voting requirements ( $\$ 216)$; voting trusts and other voting agreements ( 218$)$; informal shareholder action ( $\S 228$ ); liberal dissolution of joint venture corporations ( 2 273); dissolution upon deadlock ( $\$ 226$ ). Bradley, A Comparative Evaluation, supra note 6, at 533 .

66. Del. Code ANN. tit. 8, § 341 (a) (Supp. 1968). 
charter must contain a heading which states the name of the corporation and the fact that it is a close corporation. ${ }^{67}$ Furthermore, the charter may contain a section setting forth the qualifications of its shareholders, either by specifying those classes of persons who shall be entitled to become shareholders or by denoting those classes of persons who shall not be entitled to become shareholders. ${ }^{68}$ In addition, a corporation already in existence under the regular provisions of the General Corporation Law, if it meets the close corporation requirements, can become a close corporation by means of a charter amendment-approved by the holders of two-thirds of each class of its stock-stating that it elects to become a close corporation. ${ }^{69}$

To insure that a close corporation's stock can be subjected to an effective restriction on transferability, the Delaware close corporation statute, after referring to a provision of the General Corporation Law authorizing restrictions on the transferability of corporate stock, ${ }^{70}$ provides that if a restriction on the transfer of the stock of a close corporation is held to be unauthorized, the corporation shall nonetheless have an option for thirty days to acquire the restricted stock at a price agreed upon by the parties, or, if no such agreement can be reached, at the fair value of the stock as determined by the Court of Chancery. ${ }^{71}$ The close corporation status of a company will be involuntarily terminated if an event occurs which breaches one or more of the charter conditions necessary to qualify it as a close corporation, and the company or its shareholders "within thirty days after the occurrence of the event, or within thirty days after the event has been discovered, whichever is later" do not take whatever steps are necessary to correct the breach. ${ }^{72}$ In addition, a Delaware corporation may voluntarily terminate its status as a close corporation through a charter amendment approved by the holders of two-thirds of each class of stock, ${ }^{73}$ unless the charter requires a higher vote. ${ }^{74}$

The Delaware close corporation subchapter contains a number of provisions dealing with management and control of the close corpora-
67. Id. $\S 343(\mathrm{a})$.
68. Id. $\S 342$ (b).
69. Id. $\S 344$.
70. Id. $\$ 202$.
71. Id. $\$ 349$.
72. Id. $\S 348(\mathrm{a})-(\mathrm{b})$.
73. Id. $\$ 346(\mathrm{a})$.
74. Id. $\S 346(\mathrm{~b})$. 
tion. One of the sections $\mathrm{s}^{75}$ expressly provides that a written agreement made by the holders of a majority of a close corporation's outstanding voting stock, whether solely among themselves or with a person not a shareholder, is not invalid, as among the parties to the agreement, on the ground that it restricts the discretion or powers of the board of directors. Such an agreement has the effect of relieving the directors of liability for managerial acts and imposing that liability upon shareholders who are parties to the agreement. ${ }^{76}$ Another section $^{77}$ allows a close corporation's charter to provide that the corporation's business shall be managed by the shareholders instead of by a board of directors, with the shareholders becoming subject to all the liabilities of directors. However, a provision of this kind can be inserted in the charter by amendment only if all the shareholders, whether or not otherwise entitled to vote, approve it ${ }^{78}$ Such a provision can be deleted from the charter only if the holders of a majority of all the corporation's outstanding shares of stock, whether or not otherwise entitled to vote, vote in favor of deletion. ${ }^{79} \mathrm{~A}$ third section of this statute ${ }^{80}$ provides that no written agreement "among stockholders" (whether this means any two, a majority, or all is not clear), nor any provision of the charter or by-laws relating to any phase of the corporation's affairs (including but not limited to management of its business, declaration and payment of dividends or other division of profits, the election of directors or officers, the employment of shareholders, or the arbitration of disputes) shall be invalid on the ground that it is an attempt by the parties to treat the corporation as if it were a partnership or an effort to arrange relations among the shareholders or between the corporation and the shareholders in a manner that would be characteristic of a partnership.

The Delaware close corporation statute, moreover, gives the Court of Chancery power to appoint a custodian ${ }^{81}$ or a provisional director ${ }^{82}$ for a close corporation whose directors (or shareholders, if the corporation is managed by shareholders instead of by a board of directors) are so divided respecting the management of the corpora-

\footnotetext{
75. Id. § 350 .

76. $I d$.

77. $I d . \S 351$.

78. $I d$.

79. $I d$.

80. Id. § 354 .

81. Id. § 352(a).

82. Id. § 353(a).
} 
tion's business and affairs that the votes required for corporate action cannot be obtained, and as a result, the business of the corporation is either suffering from or is threatened with irreparable injury, or can no longer be conducted to the advantage of the shareholders generally. Finally, this statute provides that a close corporation's charter may include a provision granting to any shareholder, or to the holders of a specified number or percentage of shares, an option to have the corporation dissolved at will or upon the occurrence of a specified event or contingency; ${ }^{83}$ the charter may be amended to include such a provision by an affirmative vote of all the shareholders, whether or not otherwise entitled to vote, unless the charter specifically authorizes such an amendment by a lower vote of not less than two-thirds of the shareholders, whether or not otherwise entitled to vote..$^{84}$

The Maryland Approach. The Maryland close corporation statute defines a close corporation for its purposes as a corporation whose charter contains a statement declaring that it is a close corporation. ${ }^{85}$ Such a statement may either be contained in the original corporate charter or be included in the charter by means of an amendment approved by all of the corporation's shareholders $.^{86} \mathrm{Mar}-$ yland also requires that a clear reference to the fact that the corporation is a close corporation appear prominently at the top of the charter document and upon each certificate of the corporation's stock. ${ }^{87}$ However, the failure of any charter document or stock certificate to contain such a reference will not affect the corporation's status as a close corporation. 88

This statute does not prescribe requirements for a corporation's eligibility for close corporation status based on either the number of shareholders which the corporation has or the extent of trading in its shares. However, the statute does prohibit a close corporation from having outstanding: (1) any securities which are convertible into stock; (2) any voting securities other than stock; or (3) any transferable options, warrants, or other rights to subscribe for or purchase any of its stock. ${ }^{89}$

The Maryland close corporation statute is characterized by a

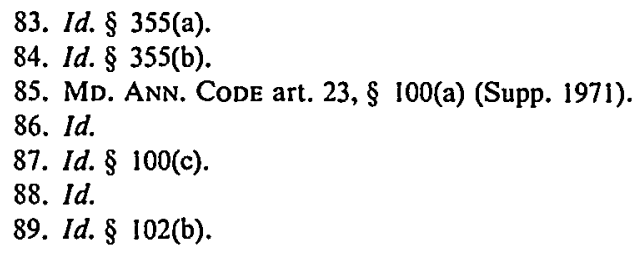


consistent requirement of unanimous shareholder approval for action that installs or modifies structural or management arrangements of fundamental importance. As noted above, unanimity is required to amend a corporation's charter to elect close corporation status. Similarly, such status, once elected, cannot be abandoned cxcept by unanimous consent..$^{90}$ Moreover, a transfer of a close corporation's shares is invalid unless it is consented to by all of the shareholders or is made pursuant to an agreement entered into by all of the shareholders.91 Further, in order to sell or issue additional shares of its stock, a close corporation in Maryland must first obtain the approval of the holders of all outstanding shares unless an agreement among its shareholders provides otherwise..$^{22}$ In addition, a shareholders' agreement regulating either the corporation's affairs or the relations of the shareholders cannot be amended except by the unanimous written consent of all shareholders then parties to the agreement. ${ }^{.3}$ Finally, approval of all of the shareholders is required for consolidation, merger, sale, lease, or exchange of all or substantially all of the corporation's assets..$^{04}$ The Maryland statute also makes it very clear that whenever it requires the consent of all of the shareholders for designated corporate action, the consent of holders of shares which otherwise do not have voting rights, or have only limited voting rights, must be obtained as well as the consent of holders of shares with full voting rights. ${ }^{95}$

Like the Delaware statute, the Maryland close corporation statute contains a number of provisions dealing with management and control. One of its sections ${ }^{96}$ permits an agreement among all of the shareholders regulating any aspect of the corporation's affairs or the relations of the shareholders, so long as it is embodied in the charter, by-laws, or in a written instrument signed by all of the shareholders. An agreement of this type may be enforced by an injunction or "by such other relief as the court may determine to be fair and appropri-

90. Id. $\S 100(b)$.

91. Id. $\S 101(\mathrm{a})$. However, unless otherwise provided by a shareholders' agreement, a shareholder is entitled to dissolve the corporation if he makes a written request for permission to transfer his shares and such consent is not given within thirty days, or if a party obligated to purchase his shares under a shareholders' agreement defaults and such default is not cured within thirty days. Id. $\S 101(b)$.

92. Id. § 102(a).

93. Id. $\S 104(\mathrm{~b})$.

94. Id. § 110.

95. Id. § 103(a).

96. Id. § 104(a). 
ate in the circumstances." ${ }^{97}$ In appropriate cases a court may, upon the motion of a party to such an agreement, order dissolution of the corporation. $^{98}$ This section also expressly states that nothing in it "shall affect otherwise valid agreements among stockholders of a close or other corporation." Another section of the statute establishes that a close corporation's charter may provide that it will have no board of directors, in which case the corporation's business and affairs shall be managed by direct action of the shareholders, exercising all of the powers given to the directors by the Maryland Stock Corporation Law. ${ }^{100}$ Such an arrangement has the effect of subjecting the shareholders to liabilities imposed upon directors by the Stock Corporation Law ${ }^{101}$ and also imposes upon shareholders responsibility to take any action formerly required to be taken by the board of directors. ${ }^{102}$

The Maryland close corporation statute also deals with a number of other important matters. For example, it provides that an annual meeting of the shareholders need not be held unless requested by a shareholder. ${ }^{103}$ In addition, the law states that a close corporation, if it chooses to have a board of directors, may fix the number of its directors at the level it desires, notwithstanding any provision in the Stock Corporation Law to the contrary. ${ }^{104}$ Furthermore, under the terms of this statute, any shareholder in a close corporation may, during the usual business hours, inspect and copy in person or through his agent or attorney the by-laws, minutes of shareholders' or directors' proceedings, annual statements concerning the corporation's affairs, the stock ledger, the corporation's books of account, and any other records or documents of the corporation relevant to its business and affairs. ${ }^{105}$ Once every calendar year, any shareholder of a close corporation may require the corporate officers to provide him with a financial statement setting out in reasonable detail the corporation's assets and liabilities as of a reasonably current date. ${ }^{106}$

\footnotetext{
97. Id. § 104(d).

98. Id.

99. Id. § 104(e).

100. Id. $\S 105(\mathrm{a})(\mathrm{l})$.

101. Id. \& 105(c)(1).

102. Id. $\$ 105(\mathrm{a})(2)$.

103. Id. $\S 107$.

104. Id. § 106.

105. Id. $\S 108(\mathrm{a})$.

106. Id. $\S 108(b)$.
} 
Moreover, a shareholder of a close corporation in Maryland may petition a court of equity for dissolution of the corporation on the ground that "there is such internal dissension among the stockholders of the corporation that the business and affairs of the corporation can no longer be conducted to the advantage of the stockholders generally." 107 However, any one or more shareholders of the corporation desiring to avoid dissolution may do so by electing to purchase the shares owned by the party petitioning for dissolution at a price equal to their fair value. ${ }^{108}$ If the shareholders concerned cannot agree on the fair value of the shares in question, the Maryland statute provides that the court considering the petition for dissolution will determine their value. ${ }^{109}$

\section{Some Suggestions for Future Close Corporation Legislation \\ Remove Unnecessary Restrictions on Participants' Contractual Freedom}

The statutes that have been enacted to meet the needs of close corporations have some serious defects. In the first place, many of the statutes designed for close corporations still impose undesirable restrictions on the freedom of the participants to set up a control pattern that allocates management powers in a manner in which they desire. ${ }^{110}$ Statutory changes, it is true, have generally been permissive and "enabling," tending to give close corporation participants greater freedom to tailor a control pattern to meet the needs of the business and their own wishes; however, questionable restrictions on the participants' contractual freedom remain.

Some statutes, for instance, seem to be characterized by the notion that an important control arrangement is not to be given effect,

107. Id. § 109(a).

108. Id. \& 109(c).

109. Id.

110. See Bradley, Towards A More Perfect Close Corporation, supra note 6, where the author examines the control arrangements that associates in close corporations typically utilize, and points out various respects in which present statutes restrict the usc of these arrangements. See also Herwitz, Allocation of Stock Between Services and Capital in the Organization of a Close Corporation, 75 HARv. L. REv. 1098, 1109-10 (1962), wherc the author notes that "a flat bar against the issuance of stock for future services is particularly unwarranted in the case of the close corporation" but that no legislative exception to the rule against issuing stock for future services has been made for the close corporation.

No legislature seems to have struggled as yet with the problem of what control a sharcholder in a close corporation should be allowed to cxert over corporate action after his death through testamentary directions as to the voting of shares. 
even among shareholders who agree to it, unless it is embodied in the corporation's charter. ${ }^{111}$ Under such a statute, inclusion of a control arrangement in the by-laws or in a shareholders' agreement, even one to which all participants are parties, will not suffice. Thus, the New York statute authorizes high quorum requirements for shareholders' and directors' meetings and high vote requirements for shareholder and director action, but only if these requirements are placed in the charter. ${ }^{112}$ That statute also indicates that an arrangement "otherwise prohibited by law because it improperly restricts the board [of directors] in its management of the business . . . or improperly transfers to one or more shareholders or to one or more persons or corporations to be selected by him or them, all or any part of such management . . . shall nevertheless be valid" if embodied in the charter of a close corporation with the approval of all of the shareholders. However, the statute does not sanction arrangements included only in the by-laws or in a shareholders' agreement. ${ }^{113}$

Experience has shown that where statutes require designated kinds of control arrangements to be embodied in the charter in order to be effective, the participants nevertheless often bargain among themselves for such control arrangements but fail to insure that the schemes are implemented by appropriate charter provisions. Perhaps this result sometimes occurs because the attorney representing the participants is unsophisticated in matters of corporate law and simply is not aware of the statutory requirements. In any event, the effect is that important contract rights cannot be enforced, the objectives of the contracting parties are frustrated, and minority participants are deprived of protection for which they bargained. ${ }^{114}$ Restrictive statutes should be amended to provide for enforcement of by-law provisions and shareholders' agreements allocating control in a close corporation, whether or not the arrangements are embodied in the charter, at least so long as shareholders who have not consented to

111. E.g., MD. ANN. Code art. 23, § 42(b) (1957); N.J. STAT. ANn. \$ 14A:5-11(1) (1969); N.Y. Bus. CORP. LAw $\$ 616$ (McKinney 1963), as amended, (McKinney Supp. 1970).

112. N.Y. Bus. CoRp. LAw $\S 616$ (McKinney 1963), as amended, (McKinney Supp. 1970).

113. Id. $\S 620(\mathrm{~b})$.

114. See, e.g., Fromkin v. Merrall Realty, Inc., 30 Misc. 2d 288, 215 N.Y.S.2d 525 (1961), affd 15 App. Div. 2d 919, 225 N.Y.S.2d 632 (1962) (shareholders' agreement forbidding sale of corporation's assets except by unanimous consent held invalid although statute authorized unanimity requirement if embodied in charter); Prigerson v. White Cap Sea Foods, Inc., 100 N.Y.S.2d 881 (Sup. Ct. 1950) (by-law requiring shareholder unanimity held invalid although statute authorized unanimity requirement if embodied in charter). 
the by-laws or who are not parties to an agreement do not complain or are not prejudiced.

Another restriction on the contractual freedom of participants occurs in statutes which limit shareholders' agreements to a period of ten years. ${ }^{115}$ Such a limitation on the term of a shareholders' agreement may make it difficult for a person coming into a close corporation in a minority position to contract for adequate protection against the power normally held by majority shareholders under the principle of majority rule. Often the first years of a business enterprise are lean years in which the business has to struggle to survive, making little, if any, profit. If a shareholders' agreement is limited to ten years, its effectiveness may lapse just as the business is developing into a highly profitable operation and seems assured of success in the future-a stage in the development of an enterprise when majority shareholders may well be tempted to squceze out a minority shareholder (that is, eliminiate him as a co-owner of the business). ${ }^{110}$ Shareholders' agreements probably have been limited in duration to ten years in some states in an effort to conform to the ten-year limitation generally applied to voting trusts; ${ }^{117}$ however, even assuming that adequate reasons exist for limiting voting trusts to ten years when they are employed in a public-issue corporation, there seems to be no justification for such a limit on a shareholdcrs' agreement used in a close corporation, especially if all of the corporation's shareholders are parties. ${ }^{118}$

A highly useful arrangement for assuring shareholders in a close corporation representation on its board of dircctors is to set up two or more classes of stock, provide that each class is to vote for and

115. See, e.g., Conn. Gen. Stat. Ann. $§ 33-339$ (1958), as amended, (Supp. 1972) (10 years with provisions for renewal provided all parties to the original agreement agree); N.C. GEN. STAT. § 55-73(a) (1965) (no provision for renewal); S.C. CODE ANN. \$\$ 12-16.15, .22(B)(3) (SUPP. 1971) (10 years with provision for renewal among concurring parties).

See also S.C. Code ANN. $\S 12-16.14$ (g) (Supp. 1971) (prescribing a maximum life of ten years for irrevocable proxies unless renewed for a period not to exceed ten years).

116. For a discussion of the techniques that are used to squeeze out a shareholder, see $F$. H. O'Neal \& J. Derwin, ExpUlsion OR OpPression of Business Associates $\$ 3.01-5.15$ (1961).

117. See Folk, The Model Act and the South Carolina Corporation Law Revision, 18 Bus. LAW. 351, 383 (1963).

118. "A close corporation statute should free all of these devices [voting trusts, shareholder voting agreements, and irrevocable proxies] from any time limitation." Bradley, Towards a More Perfect Close Corporation, supra note 6, at 1173. In some states the permissible duration of voting trusts is now longer than ten years. See, e.g., N.J. Stat. Ann. § 14A:5-20 (1969) (twenty-one years). 
elect a specified number or a specified percentage of the directors, and then issue each class to a different shareholder or faction of shareholders. Thus, the holder of Class A might elect a Class A director, the holder of Class B stock, a Class B director, and so on. In some jurisdictions, the validity of this type of arrangement has not been settled, probably because of legislative oversight. Corrective legislation is needed in those jurisdictions to make absolutely clear that this useful control arrangement is legal and is available for use in close corporations.

\section{Provide Self-Executing Protection for Minority Shareholders}

The most serious defect of current close corporation legislation is one of omission. Although most statutes validate special charter and by-law provisions and shareholders' agreements designed to protect minority shareholders, no statute-not even any one of the separate, integrated close corporation statutes-furnishes adequate selfexecuting protection for minority shareholders who have failed to bargain for special charter or by-law provisions or for protective clauses in shareholders' agreements. ${ }^{119}$ Since minority participants in a close corporation may not anticipate dissension or oppression, and indeed may be unaware of their vulnerability, they frequently fail to bargain for adequate protection against mistreatment. ${ }^{120}$ In view of this widespread failure of minority shareholders to use selfhelp, commentators and legislative draftsmen now might well turn their attention to ways of providing automatic statutory protection.

Most of the modern statutes do deal in a limited way with situations in which the participants have failed to anticipate dissension or oppression. Many statutes, for example, authorize judicial dissolution of a corporation if a deadlock occurs in its management. ${ }^{121} \mathrm{~A}$ few statutes permit the courts to appoint a provisional director to break a deadlock. ${ }^{122}$ Other statutes authorize the courts to dissolve a corpo-

119. The Maryland close corporation statute does protect a shareholder against basic changes in the initial corporate setup by requiring unanimous shareholder approval for such changes. MD. ANN. CODE art. 23, § 100(b) (Supp. 1971).

120. See Hetherington, supra note 7, at 15-19.

121. E.g., Cal. Corp. Code $§ 4651$ (West 1955); Conn. Gen. Stat. Ann. $\$$ 33-382(a) (1958), as amended, (Supp. 1972); Del. CODE ANN. tit. 8, § 226 (Supp. 1968); Ill. ANN. STAT. ch. 32, § 157.86 (Smith-Hurd 1954), as amended, (Smith-Hurd Supp. 1972); N.J. STAT. ANN. § 14A:12-7 (1969); N.Y. Bus. CoRP. LAW § 1104 (McKinney 1963); N.C. GEN. STAT. § 55125 (1965); PA. STAt. ANN. tit. 15, $\$ 2107$ (1967); Wash. Rev. COdE ANN. $\$ 23$ A.28.170 (1969).

122. Cal. Corp. Code $\S 819$ (West 1955), as amended, (West Supp. 1972); Del. CodE 
ration if the acts of the directors or those in control of it are fraudulent or oppressive, ${ }^{123}$ or to designate a custodian to manage a close corporation in which a deadlock has developed. ${ }^{124}$ The Maryland close corporation statute permits judicial dissolution of a close corporation if "there is such internal dissension among the stockholders .. . that the business and affairs of the corporation can no longer be conducted to the advantage of the stockholders generally."125 Statutes permitting the courts to break management deadlocks or to dissolve a corporation for fraud or oppression are gradually increasing in number, but these statutes do not by themselves provide adequate protection to the minority shareholder.

Professor Hetherington has suggested that a minority shareholder in a close corporation, even though he has not bargained for the privilege of withdrawing from the business, should nevertheless, if he decides he wants to dispose of his interest, be able to liquidate his investment on terms that will insure him of receiving a fair share of the enterprise's accumulated earnings. ${ }^{126}$ This result could be achieved, he points out, by giving any shareholder either the right to compel dissolution or the right to require the corporation or the other shareholders to buy his shares at a "fair" price. ${ }^{127}$

Encourage Judicial Discrimination in Applying the Principle of Majority Rule and the Business Judgment Rule

Legislatures might also try to break down the traditional reluctance of American courts to intervene in the internal affairs of corporations when dissension develops among shareholders or when minority shareholders claim that they are suffering injustices. The two

ANN. tit. 8, § 353 (Supp. 1968) (applicable to close corporations only); GA. CoDE ANN. § 22703 (1970); Mo. ANN. Stat. $\S 351.323$ (1966); PA. Stat. ANN. tit. 15, § 1384 (Supp. 1972) (applicable to close corporations only).

123. E.g., Minn. Stat. ANn. § 301.49(3) (1969); Nev. Rev. Stat. § 78.650 (1968); OHIO Rev. Code AnN. § 1701.91 (Page Supp. 1971); PA. Stat. ANN. tit. 15, § 2107(A)(2) (1967).

124. See, e.g., Del. Code ANN. tit. 8, § 352(a)(1) (Supp. 1968).

125. MD. ANN. Code art. 23, \& 109(a) (Supp. 1971).

126. See Hetherington, supra note 7 , at 22.

127. The latter alternative would require statutory provisions to permit the judicial determination, if necessary, of price. Similarly, court supervision of the terms of payment, which could be extended over a period of months or years depending on the circumstances, would prevent or mitigate the burden of raising a large amount of cash over a short period of time that could otherwise fall on the purchasers. Finally, the other shareholders could be given an option to dissolve the corporation in lieu of the purchase. Most important, of course, the statutory liquidation right, like the partner's right to compel dissolution, must be unconditional. Id. 
principal conceptual barriers to the courts' granting relief to aggrieved minority shareholders-the principle of majority rule in corporate management and the business judgment rule--actually have only limited validity in small business corporations. Apparently without close examination, courts have long accorded the principle of majority rule the same sanctity in corporate enterprises, including small businesses, that the tenet enjoys in the political world. Yet, many participants in closely held corporations are "little people," unsophisticated in business and financial matters. Not uncommonly, a participant in a closely held enterprise invests all his assets in the business with an expectation, often reasonable under the circumstances even in the absence of an express contract, that he will be a key employee in the company and will have a voice in business decisions. When courts apply the principle of majority rule in close corporations, they often disappoint the reasonable expectations of minority participants.

The indiscriminate application of the business judgment rule to sustain action of directors in a close corporation is also subject to criticism. That rule seems to be grounded on the following ideas: (1) shareholders have selected the directors to manage the business, and the courts are not justified in substituting their judgment for that of managers selected by the owners of the business; (2) directors' decisions are based on complex business considerations and courts are simply not qualified to make those decisions or to pass on their propriety in the absence of a clear abuse of discretion; and (3) a heavy burden should be placed on complaining shareholders in order to discourage strike suits and frivolous litigation.

These justifications for the business judgment rule, however, do not fully apply to the situation of a close corporation. Courts may well consider intervention to protect minority shareholders in a close corporation against oppressive action by the directors (unfair dividend policies, for example), even though fraud, bad faith or, for that matter, clear unreasonableness on the part of the directors cannot be shown. Participants in a close corporation do not usually think of themselves as delegating management of their corporation to an independent board of directors; the board is often viewed as only a legal formality. Insofar as the participants look into the future at the time they organize a close corporation, they usually anticipate that the owners will also be the managers. Minority shareholders expect to share in management.

It hardly seems necessary in all cases to say, as the courts so often 
have ruled in effect, that a person who becomes a shareholder in a corporation assumes a certain legal status with all of its built-in liabilities, irrespective of his and his associates' intentions and expectations. Furthermore, in a close corporation, where the business considerations on which directors' decisions are based are likely to be somewhat less intricate than in public-issue corporations and the directors making the decisions are likely to be somewhat less astute, there is less reason for courts to show an unquestioning deference to decisions of the directors. Finally, the great practical danger of a tooready judicial interference with public-issue corporations-the danger of encouraging strike suits-is not present in close corporations or at least not to the same degree.

A statute stating that shareholders in a close corporation, just as partners in a firm, are to be held to strict fiduciary duties to each other in the operation of the business and in their dealings among themselves might provide some protection to minority shareholders. Similarly, it might be helpful to have legislation that directs the courts, even in the absence of an express agreement, to protect the reasonable expectations of persons acquiring an interest in a close corporation-for example, their expectation to participate in management or to be employed by the company. Further, draftsmen of future close corporation legislation might consider methods of assuring that victims of torts committed by close corporations are able to recover their damages. For example, they might contemplate a statutory provision which would impose on the shareholders personal liability for corporate torts unless the corporation had provided itself with reasonably adequate liability insurance. ${ }^{128}$

\section{Provide Judicial Remedies that Give Long-Term Protection to Minority Shareholders}

Legislation to broaden the remedies available to the courts in protecting minority shareholders also seems desirable. On the whole, American courts have been singularly unresourceful in developing remedies to assist minority shareholders. Of course, the courts have compelled dishonest directors, officers, and majority shareholders to restore assets appropriated from the corporation, and they have sometimes set aside mergers and recapitalizations which were patently unfair to minority shareholders. On occasion they have even

128. See Comment, Should Shareholders Be Personally Liable for the Torts of Their Corporations?, 76 YALE L.J. 1190 (1967). 
ordered the declaration of dividends when dividends were being withheld to "squeeze out" minority shareholders. Remedies granted, however, have been largely stopgap in nature, providing relief against particularly flagrant acts by majority shareholders or by directors and officers, but usually not protecting minority shareholders against future oppression or new attempts at squeeze-outs. Courts generally have failed to provide permanent solutions when selfish and aggressive majority shareholders are searching for ways to oppress or eliminate a minority. In many instances dissolution and liquidation of a company does not benefit minority shareholders because the liquidation value of the assets may be small or the only available purchasers may be the very majority whose oppression drove the minority to seek redress. Perhaps, when dealing with a dispute among the owners of a close corporation, the courts should have, in addition to the power to dissolve a deadlocked or dispute-wracked corporation, the power to impose upon the parties whatever settlements they consider just and equitable. This discretion probably should be unfettered, because it is impossible to set forth a general guide to the solution of what are essentially individual cases. Thus, a court should have power to order the purchase of a shareholder's interest by the corporation or the other shareholders or to make whatever order it considers appropriate to regulate the future conduct of the corporation's affairs. ${ }^{129}$

129. Cf. Companies Act, 11 \& 12 Geo. 6, c. 38, § 210-(1948), which gives English courts broad power of this kind. South Carolina was the first American state to adopt similar legislation. S.C. Code ANN. § 12-22.23 (Supp. 1971). 


\section{.}

